\title{
Informeret samtykke i kliniske forsog: teknikaliteter, tillid og tætte relationer
}

\author{
Sarah Wadmann \\ Center for Sund Aldring, Institut for Folkesundhedsvidenskab, Københavns Universitet \\ sala@sund.ku.dk
}

I denne artikel undersøges kroniske patienters beslutninger om forsøgsdeltagelse og betydningen af deltagerinformation. På baggrund af et års feltarbejde på fire danske forskningsklinikker argumenterer jeg for, at de observerede patienter opererer efter andre logikker, når de tager beslutninger om at deltage $i$ kliniske forsøg, end hvad der antages $i$ den galdende forskningsetiske regulering. Feltarbejdet fulgte et klinisk logemiddelfors $\emptyset \mathrm{g}$ og inkluderede observationer afforsøgskonsultationer; interviews med investigatorer, projektsygeplejersker, fors $ø g$ sdeltagere og virksomhedsreproesentanter; samt en mindre spørgeskemaunders $ø$ gelse blandt de danske forsøgsdeltagere. Resultaterne indikerer, at for en gruppe af erfarne forsøgsdeltagere handler beslutningerne om forsøgsdeltagelse ikke om forsøget i sig selv, men om at opretholde en noer relation til forskningspersonalet. Disse patienter orienterer sig ikke efter deltagerinformation, men $i$ forhold til tillidsrelationer. De agerer ikke som autonome individer, men oplever, at de er afhoengige af sundhedssystemet. De udtrykker altruistiske motiver, men håber samtidig, at forsøgsdeltagelse vil give dem bedre helbredskontrol. For dem er forsøgsdeltagelse blevet en måde at leve med kronisk sygdom. Mulige implikationer af denne situation diskuteres, idet det understreges, at tillidsfulde relationer er en forudsoetning både for god behandling og god forskning, men at de toette relationer samtidig kan bevirke, at patienter bliver mindre kritiske, i forhold til hvilke fors $\emptyset g$ de accepterer at deltage $i, \mathrm{~g}$ at en bevidsthed om forsøgsrelaterede risici fortrcenges fra forsøgssituationen.

Keywords: informeret samtykke, deltagerinformation, deltagermotivation, kliniske forsøg, kronisk sygdom, Danmark

English summary: Informed consent in clinical trials: technicalities, trust and intimate relationships

This article explores decisions about clinical trial participation in a group of patients with chronic conditions, focusing especially on motivation for trial participation and trial information. Based on ethnographic research in four Danish hospitals in conjunction with a clinical drug trial, I argue that these patients' decisions follow logics other than those anticipated in research ethics regulations. I build on observations, interviews with physician-investigators, project nurses, patient-participants and trial sponsors, and a survey of the participants. The results indicate that for a group of experienced trial participants, trial information plays a very limited role because their decisions do not concern the trial per se but the sustainment of a close relationship with the research staff. They do not act as auto- 
nomous individuals weighing pros and cons based on the written information they receive. Rather, they feel dependent on the healthcare system and navigate in trust relations. For them, trial participation has become a way of living with chronic disease. I discuss implications of this situation underlining that trustful relationships constitute a precondition for high quality chronic care and research, yet the social dynamics may also lead patients to pay less attention to risks associated with trial participation.

Keywords: informed consent, participant information, participant motivation, clinical trials, chronic disease, Denmark

\title{
Introduktion
}

Informeret samtykke udgør i dag et dominerende reguleringsprincip til sikring af etisk forsvarlig praksis i medicinsk behandling og forskning (Manson \& O’Neill 2007: 1-25) stadfæstet $i$ internationale, etiske retningslinjer såvel som juridisk bindende lovgivning. ${ }^{1}$ Dette princip skal sikre, at forsøgsdeltagelse er frivillig, og at forsøgsdeltageres accept ikke sker på falske forudsætninger. I Helsinki-deklarationens $\$ 22$ lyder det:

\begin{abstract}
Ved al forskning på menneskelige væsener skal enhver potentiel forsøgsperson informeres i tilstrækkelig grad om forsøgets formål, metoder, finansieringskilder, alle eventuelle interessekonflikter, forskerens institutionelle tilhørsforhold samt de forventede fordele, de mulige risici og det ubehag, som undersøgelsen kan medføre. Forsøgspersonen skal informeres om sin ret til at afstå fra at deltage i undersøgelsen eller til, uden repressalier, at trække sit samtykke til deltagelse tilbage til enhver tid. Efter at have sikret sig at forsøgspersonen har forstået informationen, skal lægen så indhente forsøgspersonens frit afgivne, informerede samtykke, helst skriftligt. Hvis samtykket ikke kan indhentes skriftligt, skal det ikke-skriftlige samtykke formelt dokumenteres og bevidnes. (Oversættelse: Den Danske Lægeforening) $)^{2}$
\end{abstract}

Oftest begrundes denne regulering med respekt for forsøgsdeltageres autonomi (Beauchamp \& Childress 2013). ${ }^{3}$ Imidlertid er det siden 1980'erne (Appelbaum, Roth, Lidz, Benson \& Winslade 1987; Cassileth, Zupkis, Suttonsmith \& March 1980) gentagne gange vist, at på trods af at formelle informationsprocedurer er fulgt, har mange forsøgsdeltagere ikke forstået centrale aspekter, såsom randomisering (Behrendt, Golz, Roesler, Bertz \& Wunsch 2011; Hereu, Perez, Fuentes, Vidal, Sune \& Arnau 2010; Falagas, Korbila, Giannopoulou, Kondilis \& Peppas 2009; Featherstone \& Donovan 1998; Featherstone \& Donovan 2002; Sanchini, Reni, Calori, Riva \& Reichlin 2013), placebo-kontrol (Goetz, Janko, Blasucci \& Jaglin 2003; Hereu et al. 2010) og bivirkningsrisici (Behrendt et al. 2011; Bergenmar, Molin, Wilking \& Brandberg 2008; Falagas et al. 2009; Hereu et al. 2010; Joffe, Cook, Cleary, Clark \& Weeks 2001; Sanchini et al. 2013). ${ }^{4}$ I tråd med andre studier viste en stor spansk survey-undersøgelse blandt 140 deltagere i 40 forskellige forsøg ${ }^{5}$ eksempelvis, at mens langt størstedelen af deltagerne ( $88 \%$ ) kunne genkalde sig deres ret til at afbryde forsøgsdeltagelsen, så var under halvdelen (42\%) klar over, at interventionen kunne medføre bivirkninger, kun omkring hver fjerde (23\%) var klar over, at interventionen fordeltes efter et tilfældighedsprincip, og for dem, der deltog i et placebo-kontrolle- 
ret forsøg, var lidt over halvdelen (57\%) klar over, at de kunne modtage ikke-aktiv behandling (Hereu et al. 2010). ${ }^{6}$ Når formelle forskrifter om informeret samtykke er fulgt, hvorfor ser vi da en situation, hvor en betydelig andel af forsøgsdeltagerne tilsyneladende ikke har forstået centrale dele af de forsøg, som de lægger krop til?

Diskussioner heraf har ofte fokuseret på længden og læsevenligheden af samtykkedokumenter (se eksempelvis Berger, Gronberg, Sand, Kaasa \& Loge, 2009; Paasche-Orlow, Taylor \& Brancati 2003). Mange forsøg er blevet igangsat, hvor samtykkedokumenter er blevet revideret og/eller formidlet gennem nye medier - men ofte med begrænset effekt på deltagernes forståelse (Flory \& Emanuel 2004; Nishimura, Carey, Erwin, Tilburt, Murad \& McCormick 2013). ${ }^{7}$ Med fokus på informationsindhold og formidlingskanaler indskriver disse studier sig i en forståelse af informeret samtykke, hvor der lægges mere vægt på informationsoverførsel end på gensidig kommunikation (Manson \& O’Neill 2007: 34-38; O’Neill 2004). Denne tænkning begrænses af, at kommunikative aspekter, som beror på forskeres og forsøgspersoners agens, nedtones (Manson \& O’Neill 2007: 48-49, 68-69), og at det i vid udstrækning ignoreres, at samtykke må forstås i relation til den sociokulturelle kontekst, hvori det afgives (Corrigan 2003). Som fremhævet af McDonald, Townsend, Cox, Paterson og Lafreniere (2008) peger dette på vigtigheden af at opnå en bedre empirisk funderet forståelse af, hvad der er på færde for forsøgsdeltagere, når de træffer beslutning om at deltage i kliniske forsøg. På den baggrund er udgangspunktet for denne artikel en undren over, hvad der motiverer patienter med kroniske lidelser til forsøgsdeltagelse, og hvad deltagerinformation betyder i deres beslutningsproces.

Spidsformuleret illustrerer denne artikel en situation, hvor forskningspersonale på danske hospitaler kæmper for at få en gruppe patienter med multiple, kroniske lidelser til at interessere sig for deltagerinformation, mens patienterne kæmper for at få lov til at deltage i kliniske forsøg uden at bekymre sig synderligt om, hvad de går ud på. Jeg viser, hvordan disse patienter opererer efter andre logikker, når de tager beslutninger om at deltage i kliniske forsøg, end hvad der antages i den gældende forskningsetiske regulering: De orienterer sig ikke efter deltagerinformation, men i forhold til tillidsrelationer; de agerer ikke autonomt, men oplever afhængighed af sundhedssystemer; de udtrykker altruistiske motiver, men håber også, at forsøgsdeltagelse vil give bedre helbredskontrol. For dem er forsøgsdeltagelse blevet en måde at håndtere det at skulle leve med kronisk sygdom.

I det følgende redegør jeg først for mit teoretiske blik på deltagermotivation, inden jeg giver et kort overblik over anvendte forskningsmetoder. Herefter følger en analyse af de logikker, som former patienters beslutninger om forsøgsdeltagelse. Endelig diskuteres mulige implikationer for informeret samtykke.

\section{Deltagermotivation i kliniske forsog}

En betydelig del af litteraturen om deltagermotivation i kliniske forsøg efterstræber en afklaring af, hvorvidt forsøgsdeltagelse er motiveret af altruistiske motiver (se eksempelvis Canvin \& Jacoby 2006; Ellis 2000; McCann, Campbell \& Entwistle 2010), ${ }^{8}$ mens en 
anden del søger at fastlægge (demografiske eller psykosociale) determinanter for forsøgsdeltagelse (Ellis, 2000; Verheggen, Nieman \& Jonkers 1998). Fælles for disse studier er, at motivation ses som en iboende kvalitet, der kan formes af individuelle forventninger til deltagelse i medicinske eksperimenter. Med udgangspunkt i socialpsykologisk adfærdsteori påpeger eksempelvis Verheggen et al. (1998) i et meget citeret studie, at patienters beslutninger om forsøgsdeltagelse hviler på personlige cost-benefit afvejninger knyttet til forventninger om forsøgsrisici og tidsforbrug over for kliniske og emotionelle fordele. I modsætning hertil demonstrerer en række etnografiske studier (for eksempel Abadie 2010; Fisher 2009; Fox 1959; Petryna 2009; Rajan 2005), at deltagermotivation må forstås situeret, det vil sige, at motivation for forsøgsdeltagelse ikke kan forstås uafhængigt af den kontekst, hvori det foregår (Felt, Bister, Strassnig \& Wagner 2009; Høyer 2003). Eksempelvis er det illustreret, hvordan manglende adgang til sundhedsydelser (Fisher 2009; Petryna 2009) og indkomstmuligheder (Abadie 2010; Rajan 2005) i høj grad medvirker til at sikre rekruttering af forsøgspersoner, i hvad der forstås som «udbytning» (Abadie 2010; Rajan 2005) af vor tids underklasse af en magtfuld, kapitalistisk og videnskabelig elite. Mens en sådan kritik kan være med til at belyse vigtige strukturelle uligheder, så kan den imidlertid lede analytisk opmærksomhed væk fra andre betydende forhold. Med blandt andet fri adgang til sundhedsydelser, arbejdsløshedsunderstøttelse og forbud mod betaling for forsøgsdeltagelse tilbyder den danske velfærdsstatslige kontekst en interessant ramme, der kan bidrage til at belyse andre mekanismer end socioøkonomiske kår som forklaring på patienters forsøgsdeltagelse (Svendsen \& Koch 2008). Som Morris og Balmer (2006) har påpeget, må ethvert møde mellem forskningspersonale og forsøgspersoner forstås som sociale situationer, der er genstand for forhandling, og hvis udfald har stor betydning for gennemførslen af medicinsk forskning. Dette studie bidrager til den empiriske forskning om forsøgsdeltagere gennem en illustration af, hvordan sociale relationer mellem forskningspersonale og patienter med kronisk sygdom er med til at forme beslutninger om at deltage $\mathrm{i}$ kliniske forsøg; relationer som ofte udvikles gennem årelange kontakter, og som formes ikke blot i mødet med klinikerne på forskningsklinikken, men også af tidligere møder med sundhedsprofessionelle i andre dele af sundhedsvæsnet.

\section{Metodisk tilgang og etiske overvejelser}

Artiklen bygger på data indsamlet i forbindelse med etnografisk feltarbejde udført på fire danske hospitalsbaserede forskningsklinikker i forbindelse med et stort, internationalt lægemiddelforsøg. ${ }^{9}$ Lægemiddelforsøget var et multi-center, fase III-forsøg, hvor en behandling blev testet for kardiovaskulære effekter blandt patienter med flere samtidige, kroniske lidelser inklusive diabetes og hjertekarsygdom. Jeg var ikke involveret i lægemiddelforsøget, men fik adgang til forskningsklinikkerne efter aftale med den sponsorerende lægemiddelvirksomhed samt ansvarlige investigatorer på de enkelte sites. Fra maj, 2010, til marts, 2011, observerede jeg kontrolbesøg og andre daglige aktiviteter på forskningsklinikkerne; havde adskillige uformelle samtaler med forskningspersonale og patienter (for eksempel over frokost eller i venten på blodprøvetagning) og foretog 28 semi- 
strukturerede interviews med 10 investigatorer, 8 projektsygeplejersker, 7 forsøgsdeltagere og 3 repræsentanter fra forskningsaktive lægemiddelvirksomheder. Alle interviews blev optaget med informantens tilladelse, transskriberet verbatim og kodet (Charmaz 2006: 42-70) manuelt af forfatteren. Den semi-strukturerede interviewguide bestod af åbne spørgsmål, som ved patientinterviewene var organiseret omkring følgende temaer: a) beslutning om deltagelse i det konkrete forsøg, herunder hvordan det foregik, overvejelser om risici og betydning af deltagerinformation; b) oplevelse af forsøgsdeltagelse, herunder relationer til forskningspersonalet og forskel fra konventionel behandling; c) datarapportering, herunder hvad der vurderes som relevant og irrelevant information at formidle til forskningspersonalet og d) oplevede udfordringer ved at leve med diabetes og hjertekarsygdom. Interviews foregik efter aftale med patienten i forbindelse med et kontrolbesøg enten i et andet rum på forskningsklinikken eller i patientens hjem. Herudover foretog jeg en mindre spørgeskemaundersøgelse blandt de danske deltagere i lægemiddelforsøget $(n=56$, responsrate: $79 \%)$. Deltagerne havde mulighed for at skrive kontaktinformation og blive ringet op for at uddybe deres svar; seks benyttede denne mulighed, hvoraf fire deltog i et opfølgende telefon-interview (én svarede ikke på gentagne opkald, og én ønskede ikke at deltage).

Eftersom de danske videnskabsetiske komiteer blot behandler biomedicinsk forskning, ${ }^{10}$ har det ikke været muligt at opnå etisk godkendelse af dette studie. Det gør ikke mit ansvar for at sikre etisk forsvarlig forskningspraksis mindre, tværtimod. Af pladshensyn er det ikke muligt at redegøre for min samlede forskningsetik her, men blot nævne at jeg i mit etnografiske arbejde har efterstræbt ikke at presse informanter til deltagelse, at behandle personhenførbare data konfidentielt, at være tro mod informanternes oplevelser i mine gengivelser, og at arbejde for at forstå, hvad der er på spil for dem i givne situationer. Jeg har søgt at leve op til dette ved blandt andet at sikre mig, at forskningspersonalet på forhånd havde kontaktet patienterne, forklaret om formålet med mit studie og spurgt, om de ville acceptere min tilstedeværelse under deres kontrolbesøg. Desuden introducerede jeg patienterne for mit forskningsformål ved kontrolbesøget og forsikrede mig om, at de accepterede min tilstedeværelse. Efter at have fulgt patienterne ved et par kontrolbesøg spurgte jeg, om de ville deltage i et interview, og ved accept fremsendte jeg kortfattet, skriftligt materiale om studiet og kontaktede dem senere telefonisk for at aftale tidspunkt og sted for interviewet. Data opbevarer jeg aflåst og gengiver i anonymiseret form. Jeg har givet alle informanter mulighed for at godkende citater; nogen har desuden læst og kommenteret på mine tekster.

Hovedparten af deltagerne i lægemiddelforsøget var mænd. De fleste havde nået pensionsalderen (gennemsnitsalder 65 år med en spredning fra 58-72 år). Kombinationen af fremskreden diabetes og hjertekarsygdom gør det til en sårbar patientgruppe. Mange kæmpede således med diabetiske senfølger, såsom synsnedsættelse og sår, som ikke ville hele, en del var gangbesværede, flere havde været indlagt med hjertekarsygdom, og enkelte var i dialysebehandling. En del af patienterne havde lang erfaring med kliniske forsøg - i nogle tilfælde længere end forskningspersonalet. Mens det for $46 \%$ af de danske deltagere var første gang, de deltog i et klinisk forsøg, angav $29 \%$ i spørgeskemaundersøgelsen, at det aktuelle forsøg var deres andet eller tredje, og $25 \%$, at det minimum var 
deres fjerde forsøg. De erfarne forsøgsdeltagere udviste generelt stor loyalitet over for forskningsenhederne. De går ofte fra et forsøg til det næste og efterspørger gerne selv nye forsøg, når et aktuelt slutter. De erfarne forsøgsdeltagere, jeg interviewede, havde alle en lang sygdomshistorie med mange kontakter til sundhedsvæsnet. En del boede alene, og ingen havde en længere videregående uddannelse. Mens de erfarne forsøgsdeltagere udgør et vigtigt rekrutteringsgrundlag for lægemiddelforsøg, repræsenterer de også særlige udfordringer for forskningspersonalet, som bekymrer sig om, hvorvidt de deltager af de «rigtige» grunde. Denne artikel fokuserer derfor særligt på denne patientgruppe.

\section{Informationer, der ikke bliver læst}

«Jeg læste det sgu ikke så meget igennem. Bare jeg kommer med, så var jeg glad nok for det.» Sådan lød responsen fra en forsøgsdeltager, da jeg spurgte ham om, hvordan han oplevede den skriftlige deltagerinformation. Responsen kan måske overraske i lyset af gængse forestillinger om, at fyldestgørende information er nødvendig for, at patienter kan tage stilling til, hvorvidt de vil deltage i et klinisk forsøg. Forskningspersonalet var imidlertid ikke overrasket. De fortalte, at de må kæmpe med at få nogle patienter til at forholde sig til deltagerinformationen forud for afgivelse af samtykke. En investigator imiterede således hvordan disse patienter kort skimmede deltagerinformationen inden de sagde ja til at deltage:

\footnotetext{
Nå, men det ser fint ud - vi skal prøve en ny medicin - det ser godt ud - det er nyresygdom - det vil jeg gerne være med til. Hvad skal vi lave? Nå, men der er noget nyreundersøgelse og nogle blodprøver og noget urin. Det kan jeg godt være med til. Får jeg en taxa? Ja. O.k.!
}

På den måde antydede han, i tråd med hvad der er fundet $\mathrm{i}$ andre studier, at en del patienter ikke læser, men højst scanner deltagerinformationen for bestemte oplysninger. I den føromtalte, store spanske spørgeskemaundersøgelse angav $26 \%$ af de, der kunne huske at have fået den skriftlige deltagerinformation, at de ikke havde læst den (Hereu et al. 2010). I tråd hermed måtte forskerne bag et norsk interventionsforsøg, hvor 22 lungekræftpatienters forståelse af henholdsvis en original samt en forkortet og revideret deltagerinformation blev sammenlignet, konkludere, at revisionen ikke havde haft den ønskede effekt - ikke fordi revisionen var mangelfuld, men fordi halvdelen af patienterne slet ikke havde loest informationen (Sand, Loge, Berger, Gronberg \& Kaasa 2008). Det indikerer, at «kontekstuelle» forhold er mindst lige så vigtige som «tekstuelle» aspekter, når patienter træffer beslutninger om forsøgsdeltagelse (Høyer 2003; Sand et al. 2008). Med andre ord: Ikke blot det semantiske indhold og organiseringen af ord, sætninger, afsnit osv. i deltagerinformation er betydningsfuldt, men også den situation, hvori samtykket foregår. 


\section{Etiske «teknikaliteter»}

I tråd med hvad der er vist i andre studier (Sand et al. 2008), indikerede forsøgsdeltagerne, som jeg mødte, at praktiske forhold ofte er afgørende, når de afgør, om de skal deltage i et forsøg. For dem er det eksempelvis vigtigt, hvad der konkret kræves i form af antal besøg, hvorvidt besøgstider kan tilpasses arbejde og øvrige aktiviteter, hvor besøgene foregår, hvorvidt de kan fă transporthjælp, hvem de skal have kontakt med, hvorvidt interventionen er medicinsk eller kirurgisk, og om den er forbundet med smerte eller indlæggelse. Derimod opfattede de information om blandt andet forsøgets design, finansiering og datatilgængelighed som tekniske forhold, det ikke er op til dem at tage stilling til. I deres optik bliver forsøgsforhold, der i forskningsreguleringen betragtes som vigtige etiske forhold, altså til teknikaliteter. Sand et al. (2008) har vist, at en del patienter undlader at forholde sig til sådanne teknikaliteter, fordi de ikke oplever det som deres, men derimod de sundhedsprofessionelles ansvar. På den måde gør patienterne spørgsmålet om information og uafhængige valg til et spørgsmål om tillid (Skolbekken, Ursin, Solberg, Christensen \& Ytterhus 2005). Det peger på, at etisk ansvarlig forsøgsrekruttering ikke kun kan betragtes som et informationsproblem. Det er nødvendigt at forstå konteksten for samtykkeafgivelse og forsøgsdeltagelse - og i særdeleshed relationer mellem forsøgsdeltagere og forskningspersonale.

\section{Et sporgsmål om information? Et sporgsmål om tillid!}

Udformningen af forskningsprotokoller på kronikerområdet betyder, at patienter typisk oplever hyppige og regelmæssige kontakter til forskningspersonalet; i nogle tilfælde bliver de fulgt tæt af det samme personale over flere år. I kontrast til den stramme tidsstyring og arbejdsdeling, der karakteriserer megen kronikerkontrol i almen praksis og ambulatorier, oplevede både forskningspersonale og patienter endvidere, at der er bedre tid at tale sammen og til at «komme hele vejen rundt om patienten», som en projektsygeplejerske udtrykte det. Ofte er det nødvendigt for forskningspersonalet at få detaljeret kendskab til patientens situation og sygdomshistorik for at kunne rapportere fyldestgørende data til forsøget. Organiseringen af de kliniske forsøg bidrager dermed til at muliggøre tætte og personlige relationer mellem patienter og forskningspersonale; hvad McDonald et al. (2008) konceptualiserer som «konkret» tillid i modsætning til «abstrakt» tillid knyttet til institutioner såsom universitetshospitaler eller lægemiddelindustrien. I tråd med hvad der er vist $i$ andre studier (Fox 1959; Will 2011), bar kontrolbesøgene præg af, at patienter og personale kendte hinanden godt og i mange tilfælde delte de en fælles jargon præget af humoristiske bemærkninger. Der blev talt og spurgt engageret til familieforhold og rejseoplevelser, udvekslet julekort og små gaver, givet mange omfavnelser, og i nogle tilfælde fortalte patienterne om, at personalet havde ringet eller var kommet på besøg, hvis de var syge. Disse relationer er med til at gøre kliniske forsøg til en attraktiv ramme for kronikerkontrol - både for personale og patienter. En projektsygeplejerske fortalte eksempelvis, at hun oplever «større frihed i forhold til at kunne hjælpe patienterne», når hun er «lidt uden for det gængse system», og patienterne føler sig taget hånd om på en anden 
måde end i konventionel behandling. En af forsøgsdeltagerne konstaterede således: «I ambulatoriet var jeg patient nummer 97 eller noget [...]. De gjorde deres arbejde, men de så mig ikke», og han slog fast, at han følte sig «mere tryg ved at være i forsøget end ved min egen læge». En anden forklarede: «Jeg tror ikke, man kan sammenligne de to ting, det tror jeg altså ikke [...]. Fordi nede på det almindelige ambulatorium, det er jo en rutinemæssig sag.» I modsætning hertil følte de sig ikke som «et nummer i rækken» eller en «rutinesag» i forskningsklinikken. De følte, at der blev taget hånd om dem som personer; de følte sig trygge, fordi de følte sig set. Én omtalte det at komme på forskningsenheden som at være «med i en familie»; en anden omtalte forskningspersonalet som sine «venner»; og mange udtrykte forventning om, at forskningspersonalet «passer på» dem, at de vil «være der» for dem og «gelejde dem gennem systemet», hvis noget skulle ske med dem. Disse citater indikerer i samklang med McDonald et al.s analyse (2008), at interpersonelle tillidsrelationer er af afgørende betydning for patienters beslutning om at deltage i klinisk forskning. Mens andre har illustreret, hvordan tillid forhandles i konkrete møder mellem forsøgsdeltagere og forskningspersonale (McDonald et al. 2008; Morris \& Balmer 2006), så fremhæver disse patienter også betydningen af tidligere erfaring med behandling i andre dele af sundhedsvæsnet. Tillidsrelationer formes altså også af forhold, som i tid og sted er adskilt fra en given situation, herunder relationer til andre sundhedsprofessionelle. For de sårbare kronikere, som jeg fulgte, blev dette sat på spidsen i situationer, hvor de oplevede, at deres behov ikke blev mødt, eller de kom til at betvivle kompetencen i almen praksis, som formelt set udgør knudepunktet i dansk kronikerkontrol. Dette var tilfældet for flere af de erfarne forsøgsdeltagere. Da jeg spurgte en af dem om, hvordan han var kommet med i det konkrete forskningsprojekt, svarede han eksempelvis:

Da de sluttede det forrige projekt, så bad jeg om at komme med i et nyt. For der er mere kontrol med dig herude, end der er hos din egen læge. Der er sgu ikke noget kontrol hos din egen læge. Det er ikke alle læger, alment praktiserende læger, der har forstand på sukkersyge. [...]. Jeg er fandeme så gal på hende.

Han forklarede videre, at han ikke følte, at hans praktiserende læge havde taget «ordentligt hånd $\mathrm{i}$ hanke» med hans sukkersyge, siden han fik det konstateret 20 år tidligere, og tilskrev en del af hans nuværende problemer med diabetiske senfølger dette forhold. Uden at forholde mig til, hvordan ansvar skal placeres i den konkrete situation, så peger patientens udtalelse på, at hans oplevelse af svigt i konventionel behandling er med til at fastholde ham som mere eller mindre permanent deltager i kliniske forsøg. På den baggrund er det ikke mærkværdigt, at han og andre erfarne forsøgsdeltagere ikke oplever behov for lang betænkningstid og detaljeret information, når de træffer beslutning om at deltage i kliniske forsøg. For dem handler beslutningen om noget andet end forsøget som sådan, nemlig om at kunne forblive i forskningsklinikken og bevare relationen til personalet dér. Dette understreger, at informeret samtykke som en institutionaliseret praksis nok kan være med til at øge forskningsinstitutioners troværdighed («trustworthiness»), men at det ikke eliminerer betydningen af eller behovet for tillid (trust) (Manson \& O’Neill 2007: 163; O’Neill 2002: 165-166). 
Opsummerende kan det altså konstateres, at der er andre logikker på spil, end hvad der antages i den forskningsetiske regulering, når patienter med kroniske lidelser træffer beslutning om at deltage i kliniske forsøg. Når forsøgsdeltagelse anskues fra et patientperspektiv, tegner der sig et billede af en gruppe personer, som oplever afhængighed af sundhedssystemet, som håber, at deltagelsen i kliniske forsøg kan give bedre kontrol med deres helbred, og som orienterer sig i forhold til tillidsrelationer snarere end deltagerinformation, når de skal tage beslutninger om at deltage i kliniske forsøg. Som Annette Baier (1986: 231) har noteret, er tillidsfulde relationer ikke en moralsk værdi i sig selv: «[...] ikke alt, som trives i tillidsfulde relationer [...] bør anspores. Udnyttelse og konspiration såvel som retfærdighed og fællesskab trives bedre i en tillidsfuld atmosfære» (min oversættelse). Det er derfor nødvendigt at forholde sig til mulige implikationer af denne situation. Det er uden for rammerne af denne artikel at foretage en dybdegående, normativ analyse, om end dette vil være relevant. I stedet vil jeg på baggrund af mit etnografiske studie påpege en række implikationer, som (i det mindste) må tages i betragtning. I det følgende vil jeg argumentere for, at tillidsfulde relationer mellem forsøgsdeltagere og forskningspersonale på den ene side er en forudsætning for god forskning og patientbehandling, men på den anden side også indebærer en risiko for, at bevidsthed om forsøgsrelaterede risici udskrives af det kliniske møde. I forlængelse heraf foreslår jeg som optakt til videre undersøgelse to mulige interventioner i relation til informeret samtykke.

\section{Implikationer for informeret samtykke}

Tillid er ikke en moralsk værdi i sig selv, men tillids- og omsorgsfulde relationer mellem forsøgsdeltagere og forskningspersonale kan givetvis styrke både patientbehandling og dataindsamling. Tillidsfulde relationer kan skabe bedre forudsætninger for dialog om de helbredsforandringer, deltagerne måtte opleve undervejs i et forsøg. Når forsøgsdeltagere stoler på, at der bliver taget hånd om og fulgt op på de forhold, de bringer op, kan de forventes at være mere tilbøjelige til at fortælle om de forandringer, de observerer. Dermed forbedres forskningspersonalets muligheder for både at reagere på patienternes behandlingsbehov $o g$ sikre mere fyldestgørende data om mulige behandlingseffekter og bivirkninger (Wadmann \& Høyer under publicering). Uden at afskrive, at patienters tillid kan svigtes, så peger det på, at omsorgs- og tillidsfulde relationer er en integreret del af medicinsk vidensproduktion (Friese 2013; Langstrup \& Winthereik 2010: 116). Imidlertid kan det også være svært at forbinde ekstraordinære omsorgsrelationer med ukendte behandlingsrisici og tilfældig fordeling af behandling. Eksempelvis afviste en af de deltagere, jeg interviewede, at han gjorde sig overvejelser om risici med begrundelsen: «Jeg ved jo, at de ikke påfører én noget [...] de påfører jo ikke én noget [...], som er forkert, dårligt eller sådan noget.» En anden understregede: «Altså, det er tillid. Hvorfor skulle de proppe mig med noget, som [...]», mens andre igen lagde vægt på, at de «ikke havde skrupler», fordi «sygehusvæsnet jo er så godt», og at de ikke overvejede, om forsøgsdeltagelse var risikabelt, fordi «de altid har styr på det [på forskningsenheden]». Ligesom flere andre af deltagerne var de overbeviste om, at forskningspersonalet ikke vil lade dem deltage i noget, der kunne være risikabelt. 
Hermed overvejede de altså $i k k e$, at sikkerhed netop er et af de forhold, der er genstand for undersøgelse i kliniske lægemiddelafprøvninger og dermed også ukendt for forskningspersonalet. Personalet fortalte, at selv da studiet blev afsluttet før tid på grund af øget forekomst af bivirkninger såsom apopleksi (slagtilfælde), nyresvækkelse og hyperkaliæmi (forhøjet kaliumkoncentration i blodet der kan bevirke muskelsvaghed og hjertearytmier) i gruppen som fik den aktive behandling, reagerede patienterne typisk ikke med bekymring om risiko for eget helbred. I stedet efterspurgte flere af dem nye studier at deltage i. På den måde kan ekstraordinære omsorgsrelationer indebære en risiko for, at forsøgsrelaterede risici fortrænges, fordi det forekommer inkompatibelt med den store tillid, som forsøgspersonerne investerer i relationen til forskningspersonalet. Endelig kan en anden, men relateret implikation være, at patienter bliver mindre kritiske, i forhold til hvilke forsøg de accepterer at deltage i. I min spørgeskemaundersøgelse stillede jeg et åbent spørgsmål: Hvad kan få dig til at sige nej til at deltage $i$ et medicinsk forsøg? Ud af de 31 patienter, der svarede på spørgsmålet, nævnte 20 patienter forhold såsom bivirkningsrisiko (5), tidsforbrug og transportudgifter (5), uklart forskningsgrundlag eller mangelfuld information (5), dårligt helbred (4), smerte (2) eller dårlig «kemi med de ansvarlige» (1). Overraskende svarede 11 ud af de 31 patienter: «intet», «ingenting», eller at de ikke kunne komme i tanke om noget, der kunne få dem til at sige nej. Da jeg interviewede en af de meget erfarne forsøgsdeltagere, reflekterede han således: «Det var sådan set lige meget, hvad man havde spurgt mig om at være med til, så havde jeg jo gjort det.» Når ønsket om at forblive i forskningsregi bliver meget stærkt for nogle patienter, kan det sætte forskningspersonalet i vanskelige beslutningssituationer. De gav udtryk for, at de i nogle situationer oplever, det vil være mere rigtigt at lade patienter overgå til konventionel behandling. Samtidig oplever de imidlertid et pres fra nogle patienter om at lade dem deltage i nye forsøg, så de kan forblive i forsøgsenheden.

Som optakt til videre undersøgelse skitserer jeg på baggrund af mit etnografiske studie to muligheder for intervention i relation til informeret samtykke. For det første et skifte i opfattelsen af patienter fra forsøgssubjekter til forsøgsdeltagere (Novas 2006). Hermed betoner jeg behov for forståelse af informeret samtykke, hvor forsøgspersoner ikke blot ses som (passive) informationsmodtagere, men inddrages mere aktivt i forskningsprocessen, idet samtykke anerkendes som en gensidig transaktion, der bør leve op til normer for succesfuld kommunikation (Manson \& O’Neill 2007: 57-64, 89). Dette kunne blandt andet fremmes ved at forskningspersonalet trænes i og lægger vægt på at forklare deltagerne om forskningsagendaer og -principper. Empirisk forskning i sådanne tiltag er endnu sparsom (Nishimura et al. 2013), men det tyder på, at kommunikative teknikker og patientinvolvering har større betydning for patienters forståelse af forsøgsaspekter end systematisk formidling af information i samtykkedokumenter (Wade, Donovan, Lane, Neal \& Hamdy 2009). ${ }^{11}$ For det andet foreslår jeg et skifte fra en episodisk til en processuel opfattelse af informeret samtykke. Det indebærer, at informeret samtykke anskues ikke blot som en tidsmæssigt afgrænset aktivitet, der finder sted før forsøgsstart i forbindelse med underskrivelse af samtykkedokumenter, men som en fortløbende aktivitet (McDonald et al. 2008) fordi forskningspersonalet også aktivt forklarer om forsøget undervejs i forskningsprocessen. På den måde ville der løbende kunne påmindes om 
eksempelvis bivirkningsrisici, og ligeledes kan patienters behov for også at se andre behandlere diskuteres.

\section{Konklusion}

Mens den forskningsetiske regulering bygger på forventninger om, at beslutninger om forsøgsdeltagelse træffes af autonome, frie individer, som er drevet af altruistiske motiver, og som foretager rationelle afvejninger af mulige fordele og risici baseret på den skriftlige information, de modtager, tegner der sig et andet billede i praksis. Denne artikel har illustreret, hvordan beslutninger om forsøgsdeltagelse for en gruppe patienter med multiple, kroniske lidelser ikke kan adskilles fra deres håb om, at forsøgsdeltagelse vil føre til bedre kontrol med deres helbred, deres oplevelse af afhængighed af sundhedsvæsnet og deres udstrakte tillid til forskningspersonalet. Det rejser vigtige spørgsmål om betydningen af informeret samtykke som middel til at sikre, at patienter ikke udnyttes eller lider overlast i forbindelse med kliniske forsøg. Hvis disse patienters samlede beslutningssituation skal tages alvorligt, må det erkendes, at de forhold, som er vigtigst for dem, herunder oplevelsen af, at der bliver taget hånd om dem, og at de kan have tillid til de sundhedsprofessionelle, ikke kan rummes i en deltagerinformation. Provokerende kan man derfor spørge: Hvem beskyttes af informeret samtykke? Når der fokuseres snævert på informeret samtykke som et bærende princip for etisk praksis, så indebærer det en risiko for at gøre «den etiske opgave» til et spørgsmål om at konstatere afvigelser fra fastlagte procedurer snarere end at forholde sig til forskningens indhold, hvilke formål den tjener, hvilke vilkår den produceres under og med hvilke mulige implikationer (Brekke \& Sirnes, 2006). Det er vigtigt at arbejde for at gøre forskningsinstitutioner troværdige («trustworthy») blandt andet gennem lovfæstede krav om informeret samtykke til forsøgsdeltagelse, og ved at videnskabsetiske komitéer nøje vurderer forhold som farlighed og væsentlighed ved godkendelse af kliniske forsøg. Det kan imidlertid ikke stå alene. Erkendelsen af, at beslutninger om forsøgsdeltagelse formes i sociale relationer mellem forsøgsdeltagere og forskningspersonale, og at nogle forsøgsdeltagere ikke bekymrer sig om at læse deltagerinformation, kalder på empirisk undersøgelse af, hvordan mere genuin patientinddragelse kan sikres i forskningsprocessen, samt grundig analyse af moralske spørgsmål knyttet hertil.

\section{Tak}

Jeg ønsker at takke informanterne, som ved deres åbenhed bidrog til at muliggøre dette studie, og Nordea Fonden, som generøst sikrede studiets finansiering. Klaus Høyer samt to anonyme reviewere bidrog med værdifulde kommentarer, som har medvirket til at forbedre dette manuskript betydeligt. Stor tak til dem. 


\section{Noter}

${ }^{1}$ For en interessant analyse af historiske rødder og udbredelse af informeret samtykke i reguleringen af medicinsk praksis se Høyer (2009). Den autoritative formulering af informeret samtykke henføres i dag som regel til Helsinki-deklarationen $\$ 22$ (1964, senest revideret i 2008, se www.wma.net/en/ 30publications/10policies/b3/index.html). Se desuden Belmont-rapporten (www.hhs.gov/ohrp/humansubjects/guidance/belmont.html), UNESCOs Universal Declaration on Bioethics and Human Rights (www.unesco.org/new/en/social-and-human-sciences/themes/bioethics//bioethics-and-human-rights/ ), CIOMS og WHOs International Ethical Guidelines for Biomedical Research Involving Human Subjects (http://www.cioms.ch/publications/layout_guide2002.pdf) og ICHs Good Clinical Practice guidelines (http://www.ich.org/fileadmin/Public_Web_Site/ICH_Products/Guidelines/Efficacy/E6_R1/ Step4/E6_R1_Guideline.pdf). I Europa reguleres der desuden via disse juridisk bindende dokumenter: the Clinical Trials Directive 2001/20EC (http://www.eortc.be/services/doc/clinical-eu-directive-04april-01.pdf) samt the Convention on Human Rights and Biomedicine (http://conventions.coe.int/Treaty/en/Treaties/Html/164.htm) og dennes Additional Protocol on Biomedical Research (http://conventions.coe.int/Treaty/en/Treaties/Html/195.htm), som er omsat i national lovgivning. Se Veerus, Lexchin og Hemminki (2013) for en sammenligning af EU medlemslandes forskningsetiske regulering.

${ }^{2}$ Se: www.laeger.dk/portal/page/portal/LAEGERDK/Laegerdk/R \%C3 \%A5dgivning \%20og \%20regler/ ETIK/WMA_DEKLARATIONER/HELSINKI_DEKLARATIONEN

${ }^{3}$ Beauchamp \& Childress bog: Principles of Biomedical Ethics (2013, 7. version) er en af de mest indflydelsesrige publikationer om informeret samtykke og autonomi i medicinsk praksis. For en kritisk diskussion af begrundelsen af informeret samtykke med princippet om respekt for forsøgspersoners og patienters autonomi se Manson og O’Neill (2007: 16-22).

${ }^{4}$ Litteraturen, som måler forsøgsdeltageres forståelse af kliniske forsøg, er præget af betydelig heterogenitet i definitioner og operationaliseringer af fænomenet «forståelse» (Sand, Kaasa \& Loge 2010). Blandt andet varierer det, hvorvidt «forståelse» vurderes som evne til mundtligt at forklare givne forsøgselementer, genkalde sig specifikke informationer eller skriftligt angive korrekte svar ved multiple choice tests; hvorvidt «forstålse» vurderes umiddelbart efter samtykkeafgivelse eller uger til måneder senere, samt hvilke forsøgselementer der indgår i vurderingen af deltagernes forståelse (Sand et al. 2010). Dette vanskeliggør sammenligninger på tværs af studier og rejser principielle spørgsmål om, hvilke krav til forståelse der skal stilles, for at etiske principper kan siges at være mødt (Appelbaum 2010). Ikke desto mindre er der tale om bemærkelsesværdige resultater, som kalder på større indsigt i, hvad der foregår, når forsøgspersoner træffer beslutning om forsøgsdeltagelse.

${ }^{5}$ Data i studiet blev indsamlet prospektivt fra 2001-2002 på et større spansk hospital, idet patienter blev interviewet maksimum tre måneder efter samtykkeafgivelse. Interviewet var standardiseret, og svarene er tjekket mod protokoloplysninger. Hovedparten af forsøgene (92 \%) var såkaldt fase III-forsøg, hvor behandlingseffektivitet og sikkerhed testes i en større patientgruppe, mens resten (8\%) var fase II-forsøg, hvor særligt behandlingssikkerhed testes i en mindre patientgruppe. Cancerpatienter var ikke inkluderet i studiet.

${ }^{6}$ Det skal bemærkes, at disse gennemsnitsestimater dækker over ganske stor variation, afhængigt af om deltagerne oplevede et akut eller ikke-akut behandlingsbehov. Mens $76 \%$ af respondenterne med et ikkeakut behandlingsbehov var klar over, at de kunne modtage placebo, var det kun $23 \%$ af respondenterne med et akut behov; mens $47 \%$ af respondenterne med et ikke-akut behandlingsbehov var klar over, at der kunne være bivirkninger, var det kun $21 \%$ af respondenterne med et akut behov; og endelig var 96 $\%$ af respondenterne med et ikke-akut behandlingsbehov klar over, at de kunne afbryde deres deltagelse, mens det kun var $55 \%$ af respondenterne med et akut behov.

${ }^{7}$ Nishimura et al.s (2013) review af randomiserede, kontrollerede forsøg (RCT) inkluderer foruden interventioner med dokumentrevision og multi-medie-formidling også få interventioner med mundtlig diskussion og forskellige former for testbaseret feedback. Reviewet demonstrerer, at der er tale om litteratur, der præges af stor heterogenitet i forhold til udformning og vurdering af interventioner; blandt andet varierer metoden, hvormed «forståelse» måles og beregnes, og det varierer, hvorvidt der er tale om 
virkelige eller simulerede situationer, hvorvidt testpopulationer udgøres af patienter eller raske forsøgspersoner og om interventionen testes mod en standardkontrol. Det er derfor forbundet med betydelig usikkerhed at drage konklusioner på tværs af disse studier, særligt gennem meta-analyse. Uanset interventionsform viste en ret begrænset andel af de identificerede studier (fra $29 \%$ til $41 \%$ ) signifikante fund (Nishimura et al. 2013). Et nyligt RCT (Knapp, Raynor, Silcock \& Parkinson 2011), som grundet publikationstidspunktet ikke er medtaget i Nishimura et al.s review viser ganske positive resultater af revideret deltagerinformation blandt britiske leukæmipatienter. Andelen, der var i stand til at identificere udvalgte informationer og angive korrekt svar på spørgsmål herom, steg fra $15 \%$ (original version) til $60 \%$ (revideret version). Imidlertid er det uklart, hvordan korrekt identifikation og svarangivelse på multiple-choice-test korrelerer med «forståelse» (Sand et al. 2010).

${ }^{8}$ Typisk konkluderes det, at forsøgsdeltagere motiveres både af altruistiske motiver og ønske om egenvinding, og der foreslås begreber, såsom «svag altruisme» (Canvin \& Jaboby 2006) og «betinget altruisme» (McCann et al. 2010) til beskrivelse heraf.

${ }^{9}$ Af konfidentialitetshensyn kan jeg ikke oplyse præcist, hvilket studie der er tale om.

${ }^{10}$ Ifølge $\$ 8$ i den danske Lov om et videnskabsetisk komitésystem og anmeldelse af biomedicinske forskningsprojekter, der var gældende ved studiets iværksættelse, skulle ethvert biomedicinsk forsøg anmeldes til komitésystemet, men: «Spørgeskemaundersøgelser [og dermed interviewstudier] og registerforskningsprojekter skal kun anmeldes til en regional komité, såfremt projektet tillige omfatter menneskeligt biologisk materiale.» Nærværende studie var således ikke anmeldelsespligtigt, og de danske videnskabsetiske komitéer har kun hjemmel til at tage stilling til anmeldelsespligtige forsøg. I studieperioden blev ovennæunte lov erstattet af Lov om videnskabsetisk behandling af sundhedsvidenskabelige forsøg. Reglen om interview- og spørgeskemaundersøgelser blev videreført i den nye lovs $\$ 14$ (www.retsinformation.dk/Forms/R0710.aspx?id=137674).

${ }^{11}$ I dette observationsstudie blev 23 rekrutteringssamtaler ved et randomiseret, kontrolleret forsøg med prostata-cancer-behandling optaget, transskriberet og analyseret ved hjælp af konversationsanalyse. Det adskiller sig dermed fra tidligere studier, som fortrinsvis har bygget på retrospektiv undersøgelse af patientoplevet kommunikation. Forfatterne konkluderer, at patientledet - frem for forskerledet - samtale giver mulighed for størst forstålse, selvom disse samtaler ofte ikke følger faste strukturer givet af samtykkedokumentet. De forklarer det ved, at personalet ved patientledet samtale får bedre mulighed for at opnå kendskab til patienters overvejelser og eventuelle bekymringer, og de anbefaler, at personalet aktivt kan tilskynde patienter til at deltage aktivt i samtalen gennem anvendelse af kommunikative teknikker, såsom åbne spørgsmål, brug af pauser og opmuntringer til at fortsætte eller uddybe udtalelser.

\section{Referencer}

Abadie, R. (2010) The Professional Guinea Pig. Durham \& London: Duke University Press.

Appelbaum, P.S. (2010) Understanding «Understanding»: An Important Step Toward Improving Informed Consent to Research. AJOB Primary Research, 1 (2), s. 1-3.

Appelbaum, P.S., Roth, L.H., Lidz, C.W., Benson, P. \& Winslade, W. (1987) False Hopes and Best Data - Consent to Research and the Therapeutic Misconception. Hastings Center Report, 17 (2), s. 20-24.

Baier, A. (1986) Trust and Antitrust. Ethics, 96 (2), s. 231-260.

Behrendt, C., Golz, T., Roesler, C., Bertz, H. \& Wunsch, A. (2011) What do our patients understand about their trial participation? Assessing patients' understanding of their informed consent consultation about randomised clinical trials. Journal of Medical Ethics, 37 (2), s. 7480. 
Bergenmar, M., Molin, C., Wilking, N. \& Brandberg, Y. (2008) Knowledge and understanding among cancer patients consenting to participate in clinical trials. European Journal of Cancer, 44 (17), s. 2627-2633.

Beauchamp, T.L. \& Childress, J.F. (2013) Principles of Biomedical Ethics (7. udg.). Oxford \& New York: Oxford University Press.

Berger, O., Gronberg, B.H., Sand, K., Kaasa, S. \& Loge, J.H. (2009) The length of consent documents in oncological trials is doubled in twenty years. Annals of Oncology, 20 (2), s. 379-385.

Brekke, O.A. \& Sirnes,T. (2006) Population Biobanks: The Ethical Gravity of Informed Consent. BioSocieties, 1, s. 385-398.

Canvin, K. \& Jacoby, A. (2006) Duty, desire or indifference? A qualitative study of patient decisions about recruitment to an epilepsy treatment trial. Trials, 7, s. 32. DOI:10.1186/1745-62157-32

Cassileth, B.R., Zupkis, R.V., Suttonsmith, K. \& March, V. (1980) Informed Consent - Why Are Its Goals Imperfectly Realized. New England Journal of Medicine, 302 (16), s. 896-900.

Charmaz, K. (2006) Constructing Grounded Theory: A Practical Guide Through Qualitative Analysis. London: Sage Publications.

Corrigan, O. (2003) Empty ethics: The problem with informed consent. Sociol. Health Illn., 25 (7), s. $768-792$.

Ellis, P.M. (2000) Attitudes towards and participation in randomised clinical trials in oncology: A review of the literature. Annals of Oncology, 11 (8), s. 939-945.

Falagas, M.E., Korbila, I.P., Giannopoulou, K.P., Kondilis, B.K. \& Peppas, G. (2009) Informed consent: How much and what do patients understand? American Journal of Surgery, 198 (3), s. 420-435.

Featherstone, K. \& Donovan, J.L. (1998) Random allocation or allocation at random? Patients' perspectives of participation in a randomised controlled trial. British Medical Journal, 317 (7167), s. 1177-1180.

Featherstone, K. \& Donovan, J.L. (2002) «Why don't they just tell me straight, why allocate it?» The struggle to make sense of participating in a randomised controlled trial. Social Science \& Medicine, 55 (5), s. 709-719.

Felt, U., Bister, M.D., Strassnig, M. \& Wagner, U. (2009) Refusing the information paradigm: Informed consent, medical research, and patient participation. Health, 13 (1), s. 87-106.

Fisher, J.A. (2009) Medical research for hire - the political economy of pharmaceutical clinical trials. New Jersey: Rutgers University Press.

Flory, J. \& Emanuel, E. (2004) Interventions to improve research participants' understanding in informed consent for research - a systematic review. Jama-Journal of the American Medical Association, 292 (13), s. 1593-1601.

Fox, R.C. (1959) Experiment Perilous. Glencoe, Ill.: The Free Press.

Friese, C. (2013) Realizing Potential in Translational Medicine: The Uncanny Emergence of Care as Science. Current Anthropology, 54 (7). Lastet ned fra: http://www.jstor.org/stable/10.1086/ 670805

Goetz, C.G., Janko, K., Blasucci, L. \& Jaglin, J.A. (2003) Impact of placebo assignment in clinical trials of Parkinson's disease. Movement Disorders, 18 (10), s. 1146-1149.

Hereu, P., Perez, E., Fuentes, I., Vidal, X., Sune, P. \& Arnau, J.M. (2010) Consent in clinical trials: What do patients know? Contemporary Clinical Trials, 31 (5), s. 443-446.

Høyer, K. (2005) 'Science is really needed - that's all I know': Informed consent and the non-verbal practices of collecting blood for genetic research in northern Sweden. New Genetics and Society, 22 (3), s. 229-244.

Høyer, K. (2009) Informed Consent: The Making of a Ubiquitous Rule in Medical Practice. Organization, 16 (2), s. 267-288. 
Joffe, S., Cook, E.F., Cleary, P.D., Clark, J.W. \& Weeks, J.C. (2001) Quality of informed consent in cancer clinical trials: A cross-sectional survey. Lancet, 358 (9295), s. 1772-1777.

Knapp, P., Raynor, D.K., Silcock, J. \& Parkinson, B. (2011) Can user testing of a clinical trial patient information sheet make it fit-for-purpose? A randomized controlled trial. BMC.Med., 9, s. 89.

Langstrup, H. \& Winthereik, B.R. (2010) Producing Alternative Objects of Comparison in Healthcare: Following a Web-based Technology for Asthma Treatment through the Lab and the Clinic. I Thick Comparison: Reviving the Ethnographic Aspiration, red. T. Scheffer \& R. Niewöhner, vol. 114, s. 103-128. Leiden: Brill.

Manson, N.C. \& O’Neill, O. (2007) Rethinking Informed Consent in Bioethics. Cambridge: Cambridge University Press.

McCann, S.K., Campbell, M.K. \& Entwistle, V.A. (2010) Reasons for participating in randomised controlled trials: Conditional altruism and considerations for self. Trials, 11, s. 31.

McDonald, M., Townsend, A., Cox, S.M., Paterson, N.D. \& Lafreniere, D. (2008) Trust in Health Research Relationships: Accounts of Human Subjects. Journal of Empirical Research on Human Research Ethics, 3 (4), s. 35-47.

Morris, N. \& Balmer, B. (2006) Volunteer human subjects' understandings of their participation in a biomedical research experiment. Social Science \& Medicine, 62 (4), s. 998-1008.

Nishimura, A., Carey, J., Erwin, P.J., Tilburt, J.C., Murad, M.H. \& McCormick, J.B. (2013) Improving understanding in the research informed consent process: A systematic review of 54 interventions tested in randomized control trials. Bmc Medical Ethics, 14, s. 28. DOI:10.1186/17456215-7-32.

Novas, C. (2006) The Political Economy of Hope: Patients' Organizations, Science and Biovalue. BioSocieties, 1, s. 289-305.

O'Neill, O. (2002) Autonomy and Trust in Bioethics, Cambridge: Cambridge University Press.

Paasche-Orlow, M.K., Taylor, H.A., \& Brancati, F.L. (2003) Readability standards for informedconsent forms as compared with actual readability. New England Journal of Medicine, 348 (8), s. 721-726.

Petryna, A. (2009) When Experiments Travel: Clinical Trials and the Search for Human Subjects, New Jersey \& Oxfordshire: Princeton University Press.

Rajan, K.S. (2005) Subjects of speculation: Emergent life sciences and market logics in the United States and India. American Anthropologist, 107 (1), s. 19-30.

Sanchini, V., Reni, M., Calori, G., Riva, E. \& Reichlin, M. (2013) Informed consent as an ethical requirement in clinical trials: An old, but still unresolved issue. An observational study to evaluate patient's informed consent comprehension. Journal of Medical Ethics. Lastet ned fra: http://jme.bmj.com/content/early/2013/05/30/medethics-2012-101115.abstractt

Sand, K., Loge, J.H., Berger, O., Gronberg, B.H. \& Kaasa, S. (2008) Lung cancer patients' perceptions of informed consent documents. Patient Education and Counseling, 73 (2), s. 313-317.

Sand, K., Kaasa, S. \& Loge, J.H. (2010) The Understanding of Informed Consent Information Definitions and Measurements in Empirical Studies. AJOB Primary Research, 1 (2), s. 4-24.

Skolbekken, J., Ursin, L.Ø., Solberg, B., Christensen, E. \& Ytterhus, B. (2005) Not worth the paper it's written on? Informed consent and biobank research in a Norwegian context. Critical Public Health, 15 (4), s. 335-347.

Svendsen, M.N. \& Koch, L. (2008) Between Neutrality and Engagement: A Case Study of Recruitment to Pharmacogenomic Research in Denmark. BioSocieties, 3 (4), s. 399-418.

Veerus, P., Lexchin, J., \& Hemminki, E. (2013) Legislative regulation and ethical governance of medical research in different European Union countries. Journal of Medical Ethics. Lastet ned fra: http://jme.bmj.com/content/early/2013/05/09/medethics-2012-101282.abstract 
Verheggen, F.W.S.M., Nieman, F. \& Jonkers, R. (1998) Determinants of patient participation in clinical studies requiring informed consent: Why patients enter a clinical trial. Patient Education and Counseling, 35 (2), s. 111-125.

Wade, J., Donovan, J.L., Lane, J.A., Neal, D.E. \& Hamdy, F.C. (2009) It's not just what you say, it's also how you say it: Opening the 'black box' of informed consent appointments in randomised controlled trials. Social Science \& Medicine, 68 (11), s. 2018-2028.

Wadmann, S. \& Hoeyer, K. (under publicering) Beyond the 'therapeutic misconception': Research, care and moral friction. BioSocieties.

Will, C. (2011) Mutual benefit, added value? Doing research in the National Health Service. Journal of Cultural Economy, 4 (1), s. 11-25. 